\title{
Organoleptic Characteristics of Rimau Gerga Lebong (RGL) Orange Coated With Cassava Peel Starch and Chitosan Saved at Temperature Room For 20 Days
}

\author{
Adwini Prasetya ${ }^{1}$, Siska Apriani ${ }^{1}{ }^{*}$, dan Sigit Mujiharjo ${ }^{2}$ \\ ${ }^{1}$ Jurusan Teknologi Pertanian Fakultas Pertanian Universitas Dehasen Bengkulu \\ Jl. Meranti Raya No. 32 Sawah Lebar, Kota Bengkulu \\ 2Jurusan Teknologi Pertanian Fakultas Pertanian Universitas Bengkulu \\ Jl. WR Supratman, Kandang Limun, Kota Bengkulu \\ E-mail: doshigi@yahoo.com
}

\begin{abstract}
Consumers' preference level, especially on agricultural or food products, can be used as a benchmark measure or determine the market or shelf life of the product. This research aims to determine organoleptic quality through the level of people's preference for RGL citrus fruits coated with edible coating starch from cassava peel plus chitosan. Aplication of coating on the fruits and storage layout of this study was conducted following a completely randomized design (CRD) with 2 different factors; cassava skin starch concentration; namely $3 \%, 5 \%$, and $7 \%$; and chitosan concentration; i.e. $0 \%, 0.5 \%, 1 \%$, $1.5 \%$. The observed variables are the panelists' preference level with organoleptic test on color, flavor, texture and taste of RGL orange that has been treated and stored at room temperature for 20 days. Research result indicates that the color of the orange that the panelists favored is absent; the level of panelist most prefer is neutral, if the starch is 3\% with chitosan $0 \%$ (preference score 3.92); and if the starch $7 \%$ with chitosan $0.5 \%$ (score 3.44). The preferred aroma of orange is absent; the level of panelist highest preference on aroma is neutral, if the starch is $5 \%$ with chitosan $1.5 \%$ (score 3.12 ); and if the starch $7 \%$ with chitosan $0.5 \%$ (score 3.04). The texture of the orange is preferred to be absent; the level of panelist higherst preference on texture is neutral, if the starch is $7 \%$ with chitosan $0.5 \%$ (score 3.60 ); and if the starch is 3\% with chitosan $0.5 \%$ (score 3.56). The taste of citrus fruits is preferred if the starch is $7 \%$ with chitosan $0.5 \%$ (score 4.00 ); and if the starch is $3 \%$ with chitosan $0 \%$ (score 3.44 ). Therefore, RGL citrus fruits can be stored at room temperature for up to 20 days, if it is coated with $7 \%$ cassava peel starch with $0.5 \%$ chitosan.
\end{abstract}

Keywords : Cassava peel starch, chitosan, organoleptic preference, shelf life of RGL oranges.

Reference to this paper should be made as follows :

Prasetya, A., S. Apriani, and S. Mujiharjo. 2019. Organoleptic Characteristics of Rimau Gerga Lebong (RGL) Orange Coated With Cassava Peel Starch and Chitosan Saved at Temperature Room For 20 Days. Agritropica: Journal of Agricultural Science. 3 (1): 13-21. Doi:

https:// doi.org/10.31186/Jagritropica.3.1.13-21

\section{INTRODUCTION}

Rimau Gerga Lebong (RGL) orange is a regional orange of Lebong regency which is the one of outstanding citrus fruits of Bengkulu Province. This orange has an elliptical in shape (clavate-ovoid), yelloworange in colour, thick in skin $(0.4-0.5 \mathrm{~cm})$, large in size (173-347 grams), sweet and sour in taste of fresh fruit flesh (Rambe et al, 2012), which makes this oange look more interesting than other oranges. However, this RGL orange has a fairly high water content, averaged 89.2\% (Rambe et al, 2012), that makes this orange has a short shelf life span as it rots quickly, especially when it is stored at room temperature (Wilda et al., 2015); therefore, technologies that could extend its shelf life; including application of edible coating are needed. 
Cassava skin is a waste of household industry producing tape, cassava chips and "opak". This waste has not been widely used, only partially used as animal feed. Based on BPS (2017), cassava harvest area in Bengkulu Province during 2015 reached 3,573 ha with a production of 80,309 tons. Usually cassava skin contents about $20 \%$; and according to Akbar et al., (2013); starch contents in cassava skin ranges $44-59 \%$. By seeing the abundant amount and easily obtained because of the many cassava processing industries, producing starch from cassava skin is very potential to be developed and the product could be used as the raw material of edible coating.

Cassava starch is one type of polysaccharide that is easily biodegraded (biodegradable), easily obtained, and inexpensive. The properties of cassava starch are also suitable for edible materials coating; among others (a) it reduces water activity on the surface of the material, (b) it can improve the surface structure of materials, (c) can reduce the occurrence of dehydration, (d) blocking oxygen contact with the material, (e) the original nature of the product such as no flavour undergo changes, and (f) can improve the appearance of the product (Widaningrum et al.,2015). However, starch is resistance to water and barrier to low water vapor that it is easily damaged or torn out which causes the shelf life to be less than optimal. Another disadvantage is that the elasticity of the thin layer of cassava starch is low (Winarti et al, 2012).

In order to improve the physical characteristics and also the usefulness of cassava starch, it is necessary to add biopolymers or other materials which are hydrophobic and made anti-microbial properties; namely chitosan (Chillo et al., 2008 in Sarwono, 2010). Chitosan has been widely used as material for making biodegradable films and food preservatives which is resistant to microbes. Chitosan has anti-microbial properties with a spectrum broad, both against bacteria, fungi and mold (Winarti et al, 2012) .
Study on the use of starch from cassava peel as an edible coating with addition of chitosan as an antimicrobial that can be applied to extend the shelf life of RGL oranges which is a superior commodity in Bengkulu province is very highly required. Apart from the cassava peel which is a waste so it has great potential if it is utilized in order to reduce the use of starch used for food consumption has not been done. As the final destination of the extension of shelf life is to maintain quality both in terms of physical, chemical, nutritional or microbiological content, the quality related to the level of acceptance or people's liking for the sensory characteristics of oranges RGL which will determine the feasibility of selling of this fruit is also very necessary. This research is parts of preserving RGL orange efforts that aims to explain the level of community acceptance of RGL citrus fruits treated with edible coating starch from cassava peel plus chitosan.

\section{MATERIAL AND METHODS}

\section{Materials}

The basic material of edible coating in the form of cassava peel used in this study was obtained from household industrial waste making chips, tape and "opak" in the city of Bengkulu. The skin part of the cassava that is taken is the pink inner part or yellowish white colored part, depending on the type of cassava. Red cassava peel generally thicker and easier to be processed than white cassava peels thinner.

RGL citrus fruits treated in this study were obtained from the citrus orchards in the village of Rimbo Pengadang, Lebong Regency. RGL oranges used in this research is the result of sorting based on uniformity of maturity, size, weight, no blisters skin, bruises, no rot and other damage. Sorted orange fruit then cleaned uses a clean cloth.

\section{Research Method}

Implementation of edible coating to the fruits and storage layout in this study was carried out following Complete Random Design (CRD) with based on two 
factors; that are the concentration of cassava starch apply; 3\%, 5\%, 7\% (w/v); and the concentration of chitosan used; $0 \%, 0.5 \%, 1 \%$, $1.5 \%(\mathrm{w} / \mathrm{v})$. Each treatment was repeated 3 times and observed on the $20^{\text {th }}$ of storage day. The combined treatments of this study can be seen in Table 1.

Table 1. Combinations of the treatment of edible coatings

\begin{tabular}{|c|c|c|c|c|c|c|c|c|c|c|c|c|}
\hline \multirow{2}{*}{$\begin{array}{c}\text { Replica } \\
\text { tion }\end{array}$} & \multicolumn{3}{|c|}{$\mathrm{B} 1(0,0 \%)$} & \multicolumn{3}{|c|}{$\mathrm{B} 2(0,5 \%)$} & \multicolumn{3}{|c|}{ B3(1,0\%) } & \multicolumn{3}{|c|}{$\mathrm{B} 4(1,5 \%)$} \\
\hline & A1(3\%) & $\begin{array}{l}\mathrm{A} 2(5 \% \\
)\end{array}$ & A3(7\% & $\begin{array}{c}\mathrm{A} 1(3 \% \\
)\end{array}$ & $\begin{array}{l}\mathrm{A} 2(5 \% \\
)\end{array}$ & A3(7\% & $\begin{array}{c}\mathrm{A} 1(3 \% \\
)\end{array}$ & $\begin{array}{l}\mathrm{A} 2(5 \% \\
)\end{array}$ & A3(7\% & $\begin{array}{c}\mathrm{A} 1(3 \% \\
)\end{array}$ & $\begin{array}{l}\mathrm{A} 2(5 \% \\
)\end{array}$ & $\begin{array}{l}\mathrm{A} 3(7 \% \\
)\end{array}$ \\
\hline & & & & & & A3B2 & & & & & & \\
\hline U1 & $\begin{array}{c}\text { A1B1 } \\
\text { U1 }\end{array}$ & $\begin{array}{c}\text { A2B1 } \\
\text { U1 }\end{array}$ & $\begin{array}{c}\text { A3B1 } \\
\text { U1 }\end{array}$ & $\begin{array}{c}\text { A1B2 } \\
\text { U1 }\end{array}$ & $\begin{array}{c}\mathrm{A} 2 \mathrm{~B} 2 \\
\mathrm{U} 1\end{array}$ & U1 & $\begin{array}{l}\text { A1B3 } \\
\text { U1 }\end{array}$ & $\begin{array}{c}\text { A2B3 } \\
\text { U1 }\end{array}$ & $\begin{array}{c}\text { A3B3 } \\
\text { U1 }\end{array}$ & $\begin{array}{c}\text { A1B4 } \\
\text { U1 }\end{array}$ & $\begin{array}{c}\mathrm{A} 2 \mathrm{~B} 4 \\
\mathrm{U} 1\end{array}$ & $\begin{array}{c}\text { A3B4 } \\
\text { U1 }\end{array}$ \\
\hline U2 & $\begin{array}{c}\text { A1B1 } \\
\text { U2 }\end{array}$ & $\begin{array}{c}\text { A2B1 } \\
\text { U2 }\end{array}$ & $\begin{array}{c}\text { A3B1 } \\
\text { U2 }\end{array}$ & $\begin{array}{c}\text { A1B2 } \\
\text { U2 }\end{array}$ & $\begin{array}{c}\mathrm{A} 2 \mathrm{~B} 2 \\
\mathrm{U} 2\end{array}$ & $\begin{array}{c}\text { A3B2 } \\
\text { U2 }\end{array}$ & $\begin{array}{l}\text { A1B3 } \\
\text { U2 }\end{array}$ & $\begin{array}{c}\text { A2B3 } \\
\text { U2 }\end{array}$ & $\begin{array}{c}\text { A3B3 } \\
\text { U2 }\end{array}$ & $\begin{array}{c}\text { A1B4 } \\
\text { U2 }\end{array}$ & $\begin{array}{c}\mathrm{A} 2 \mathrm{~B} 4 \\
\mathrm{U} 2\end{array}$ & $\begin{array}{c}\text { A3B4 } \\
\text { U2 }\end{array}$ \\
\hline U3 & $\begin{array}{c}\text { A1B1 } \\
\text { U3 }\end{array}$ & $\begin{array}{c}\text { A2B1 } \\
\text { U3 }\end{array}$ & $\begin{array}{c}\text { A3B1 } \\
\text { U3 }\end{array}$ & $\begin{array}{c}\text { A1B2 } \\
\text { U3 }\end{array}$ & $\begin{array}{c}\mathrm{A} 2 \mathrm{~B} 2 \\
\mathrm{U} 3\end{array}$ & $\begin{array}{c}\text { A3B2 } \\
\text { U3 }\end{array}$ & $\begin{array}{c}\text { A1B3 } \\
\text { U3 }\end{array}$ & $\begin{array}{c}\text { A2B3 } \\
\text { U3 }\end{array}$ & $\begin{array}{c}\text { A3B3 } \\
\text { U3 }\end{array}$ & $\begin{array}{c}\text { A1B4 } \\
\text { U3 }\end{array}$ & $\begin{array}{c}\text { A2B4 } \\
\text { U3 }\end{array}$ & $\begin{array}{c}\text { A3B4 } \\
\text { U3 }\end{array}$ \\
\hline
\end{tabular}

\section{Process of Applying the Edible Coating}

\section{Producing cassava starch}

Producing starch from cassava peel is carried out by washing cassava peel for remove dirts that clings by using clean running water. Cassava skin then cut into 1 $\mathrm{cm}$ sizes to increase surface contact with water. Then, the pieces are soaked in water for 24 hours with every 8 hours done water replacement to remove $\mathrm{HCN}$. The cassava skin is then drained, mashed and ground; and then added with water as much three times as the amount of cassava peel. The cassava pulp is then filtered by using a clean cloth to get clean starch. Filter water is then precipitated for 24 hours so that the starch settles, which is marked by the clearer water on top. Furthermore, the water is disposed of, little by little, then drained. The white solid obtained is then dried using an oven at $60 \circ \mathrm{C}$ for 8 hours. The starch obtained was then mashed with a blender and sieved with an 80 sievemesh to produce fine starch for easy homogenization with chitosan.

\section{Making edible coating of cassava starch- chitosan}

The making of edible coatings refers to Camatari et al. (2017) and Misni et al. (2017); where cassava starch is dissolved in aquades and chitosan is dissolved in acetic acid, then both solutions were homogenized and added with glycerol. Comparison between cassava starch with chitosan is a suitable treatment; namely the concentration of cassava skin starch 3\%,5\%,7\% (w/v) and chitosan concentration: $0 \%, 0.5 \%, 1 \%, 1.5 \%$ $(\mathrm{w} / \mathrm{v})$.

\section{RGL Oranges Coating and Storage}

RGL oranges that have been prepared are then coated with edible coating by means of dip it into the edible coating of cassava peel starch-chitosan according to the treatment. When dyeing ensured that all parts of the orange were coated with edible coating, then the RGL citrus fruits lifted, and dried. The RGL fruits then placed in a hollow container so it has air circulation that the edible coating layer dries quickly. Storage of fruit that has been given the treatment is carried out at room temperature, with the layout following a completely randomized design, where storage time is carried out for 20 days.

\section{Organoleptic Test}

Organoleptic test was carried out involving 25 untrained panellists for organoleptic quality of RGL citrus fruits that have been treated. Assessments include 
color, flavor, texture, taste, and overall appearance. Panelists give values following the level his favorite; that is very like, like, neutral, dislike, and very dislike. Every level are scored from 1 (very dislike) to 5 (very like).

\section{Data analysis}

Observation data are tabulated and plotted in a bar graph for viewing the effect of each treatment on the organoleptic characteristics of RGL citrus fruits for 20 days storage. Data were also analyzed by using Analysis of Variance (ANOVA) with $95 \%$ confidence level $(\mathrm{P}<0.05)$ to find out statistically the effect of treatment. If a significant difference or very significant difference is found, then the Duncan Multiple Range Test (DMRT) at a 95\% confidence level is carried out.

\section{RESULTS AND DISCUSSION}

\section{Level of Organoleptic Colour Quality of RGL Orange}

Organoleptic test results of the RGL citrus fruits coated with starch of cassava peel plus chitosan and stored for 20 days; generally shows, that the more percentage of starch used to coat, the less the level of panelists' preference for the color of the RGL orange; as well as the more chitosan added. Statistically, the amount of starch and of chitosan being applied in this study, individually or together, have a significant effect $(p<0.5)$ on the level of panellist preference for the color of RGL orange. Figure 1 shows the graph of panelist level preference for the color of RGL orange treated and the DMRT analysis results.

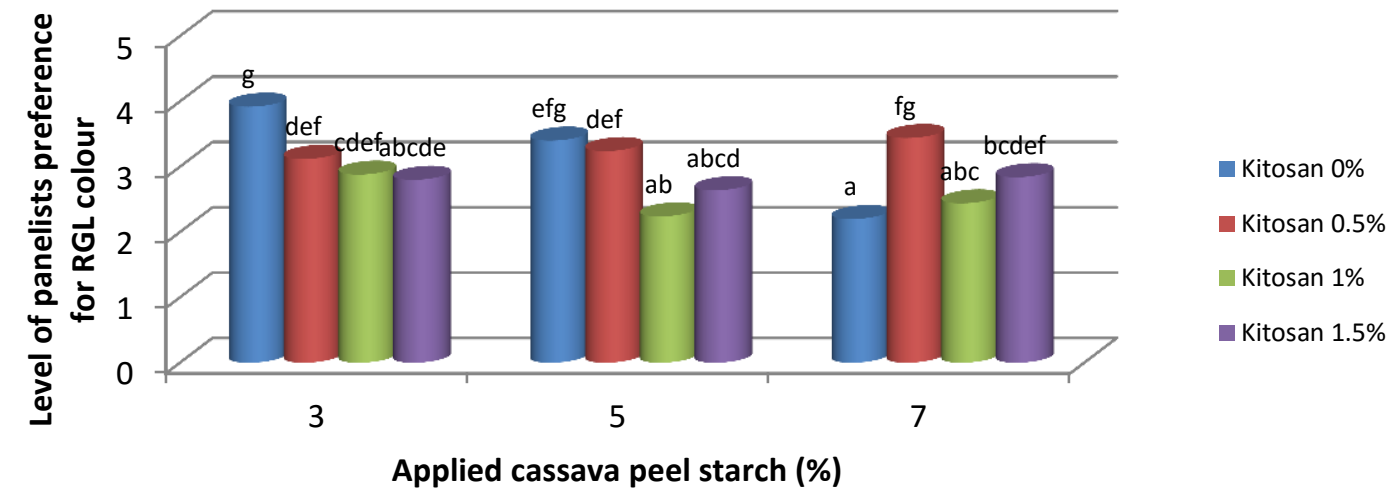

Note: the same notation above each treatment shows no significant difference at $5 \%$ level

Figure 1. Graph of panelist preference level on the color of RGL citrus fruits coated in starch cassava peels plus chitosan and stored at room temperature for 20 days

It can be seen from Figure 1 that the color of RGL orange that panellists most preferred are the one that belongs to the RGL coated with $3 \%$ cassava starch with $0 \%$ chitosan; though the level of preference is not significantly different from the one with the starch is $3 \%$ without chitosan or from the one that the starch is $7 \%$ with the addition of chitosan $0.5 \%$. In Figure 1 it can also be seen that the lowest score of panelist preference for color of RGL is the one that cassava starch $7 \%$, with chitosan $0 \%$. This level of liking is influenced by colour of the skin of RGL as the result of applying coating, more and more concentration of added cassava starch will cause coating buildup on the skin of the fruit after dyeing, that leaves a brownish color after drying.

However, the highest level of panelist preference for color is also on cassava starch $3 \%$, with $0 \%$ chitosan. The use of cassava starch without chitosan with low concentration has a higher preference level. This is in line with the results of Fajri and Santi (2018) research, using pectin, the 
mango fruit indicates that the color of the fruit is relatively stable (unchanged), coating inhibits change color because it will slow down the degradation of chlorophyll because of the high concentration of $\mathrm{CO}_{2}$ in fruit will be preserved. In addition, the decrease in chitosan concentration has higher scores or likes. The results of Fajri and Santi (2018) research in the study on mango fruit produces a faster change in color of yellow mango due to the yellow color by chitosan solvents in the form of acid solvents. Abscisic acid (ABA) will initiate ethylene production so that there will be changes in skin color and softening of the fruits.

\section{Organoleptic Flavour Quality of Orange}

In general, the level of panelist preference for the flavour of RGL citrus fruits increased with increasing amount of chitosan added; although statistically the increase was not significant. Generally panelists do not like to approach neutral (values 2.48 - 2.92; and 3.12) in fruit RGL oranges that have been stored for 20 days even though they have been coated with cassava starch plus chitosan; especially if the cassava starch used is $3 \%$ or $5 \%$. If cassava starches are $1.5 \%$; then generally panelists really don't like it (values 2.00 - 2.40); except if chitosan is $1.0 \%$; the panelists' preference level becomes neutral (value 3.04). Analysis of variance showed a significant difference in treatment $(\mathrm{p}<0.05)$, in the treatment $7 \%$ starch. Graph of panelist preference level for RGL citrus fruit flavour completed with the results of the DMRT analysis, presented in Figure 2.

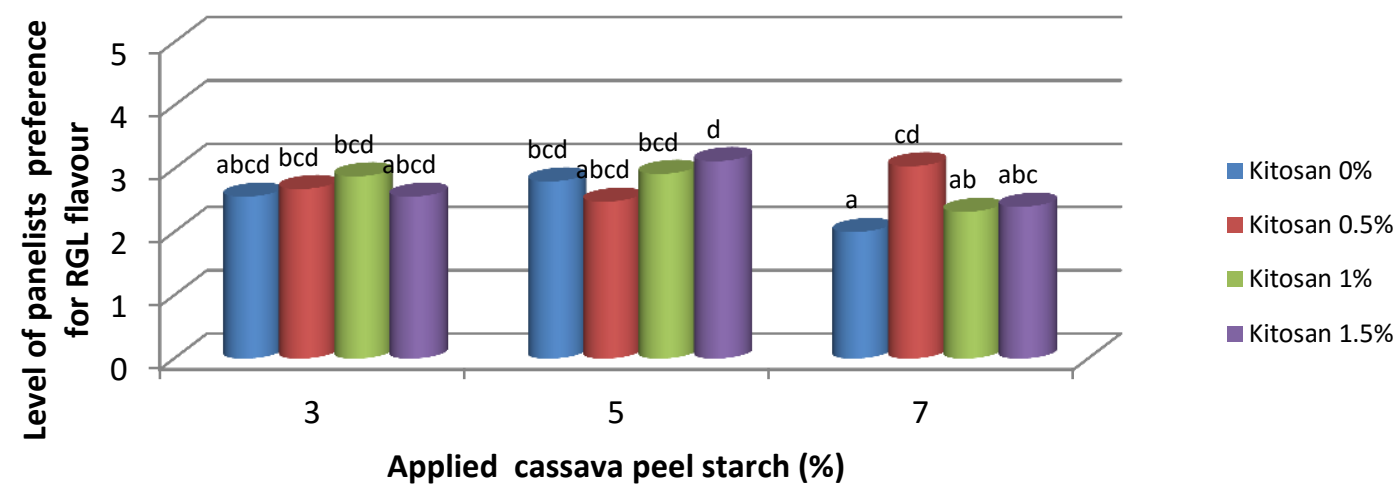

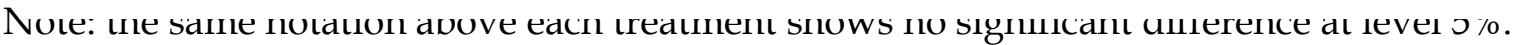

Figure 2. Graph of the panelists' preference level for the flavour of RGL citrus fruits coated with cassava starch with chitosan and stored at room temperature for 20 days

In Figure 2 can be seen, the highest level of panelists' preference for the flavour of RGL citrus fruits is when the starch is $5 \%$ with chitosan $1.5 \%$ with a value of 3.12 (slightly above neutral) and the lowest is when $7 \%$ starch with $0 \%$ chitosan; which shows that panelists generally don't like the flavour of RGL citrus fruits if stored for up to 20 days even though it has been coated with cassava starch plus chitosan.

The value of flavour preference is influenced by the presence or absence of fragrance that is smelled by panelists. The flavour of RGL orange fruit is formed during the fruit ripening process. According to Julianti (2011) the longer the storage is carried out at room temperature causes impairment of preference. Renovation of complex organic materials that occurred during the respiration process will produce simple sugars and organic acids that will affect the flavour of the fruit (Wills et al., 1981 ; Heatherbell et al., 1982). 
Organoleptic Texture Quality of RGL Orange

Organoleptic test results of the panelists' preference level for the texture of RGL citrus fruits coated with cassava starch plus chitosan showed that there are interaction between treatments; when the percentage of cassava starch is $3 \%$ then the level of panelists preference for RGL texture decreased with increasing of percentage of chitosan; when the starch is $5 \%$; panellists preference is relatively unaffected by addition of chitosan; and when the starch is $7 \%$, panellists preference is generally increase with the increase in chitosan used; though statistically the difference is generally not significant. Figure 3 shows the graph of panelists' preference level for RGL citrus fruit texture complemented with its DMRT analysis.

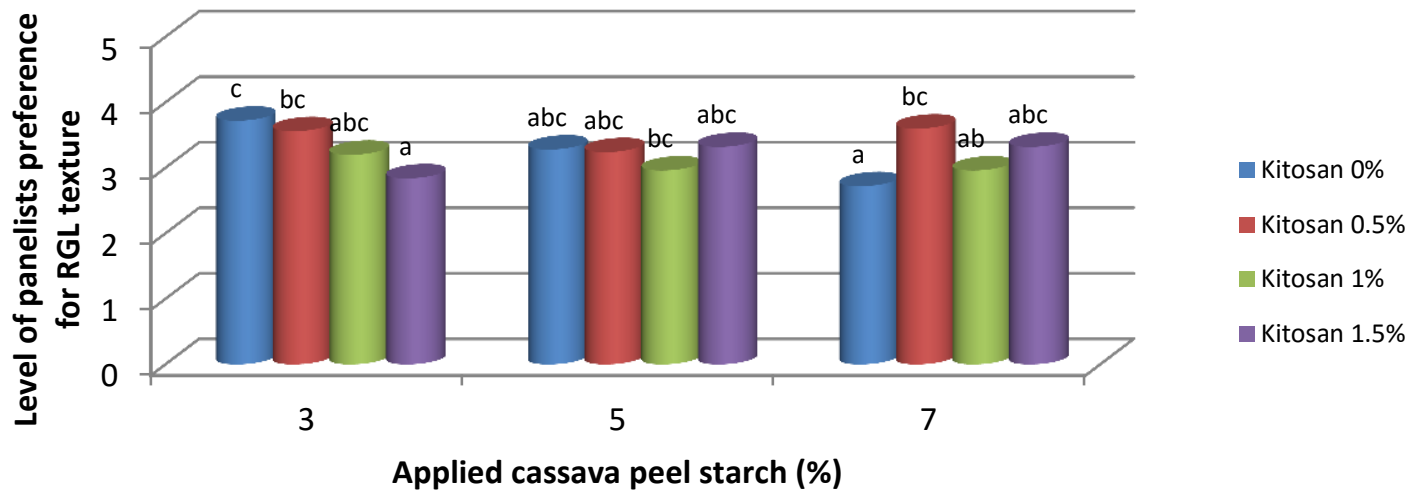

Note: the same notation above each treatment shows no significant difference at the $5 \%$.

Figure 3. Graph of panelist preference level on the texture of the coated RGL orange cassava starch plus chitosan and stored at room temperature for 20 days

In Figure 3, the highest level of panelists' preference for the texture of RGL orange is when cassava starch is $3 \%$ and chitosan $0 \%$. Level of panelists preference for the texture of RGL orange are between 2.8-3.7; it means that the panellists preference for texture of RGL citrus fruit that has been stored for upn20 days are still has decent violence for consumption, even though there are wrinkles appears on the orange peel. On some treatments, RGL citrus fruit has a very soft texture, that thought to decrease the level of panelist preference.

\section{Organoleptic Taste Quality of RGL Orange}

Percentage of cassava starch and percentage of chitosan used in edible coating for wrapping RGL citrus fruits has an interaction effect on the assessment panelist on the taste of the orange fruit. If the chitosan is $0 \%$, the more percentage of starch used would causes the lower the panelists' preference for RGL citrus fruit flavor; if the amount of chitosan is $0.5 \%$ or $1.5 \%$; the more starches are used then the level of preference for panelists tends to increase; and if the amount of chitosan which was added is $1.0 \%$, with increasing numbers of cassava starches being used; would causes the panelist preference level on RGL citrus fruit initially decreased, then increase again; although statistically these differences are not significant; except for treatments with $7 \%$ starch with $0.5 \%$ chitosan; which is the treatment that produces the panelists' most preferred taste; and treatment with 5\% starch with $1.0 \%$ chitosan, which is the treatment that produces the least taste panelists prefer. Figure 4 shows the panelists' favorite graph on the taste of RGL citrus fruits with DMRT test results.

From Figure 4 it can be seen that the highest level of panelists' preference for RGL citrus fruit taste is when cassava starch is $7 \%$ and chitosan is $0.5 \%$. This is possible 
because of the maximum work of starch to maintain high concentrations of $\mathrm{CO}_{2}$ in fruit and the influence of chitosan that initiates ethylene production so that it will occur softening of fruit (Fajri and Santi, 2018). The occurrence of softening indicates the hydrolysis of carbohydrates into glucose and fructose compound during storage and working edible coating that is not good. This also relates to taste that are less liked by panelists, however in a certain time cause sweetness in the fruit. Increasing of chitosan concentration if coupled with high starch concentrations will also increase liking panelist with respect to taste.

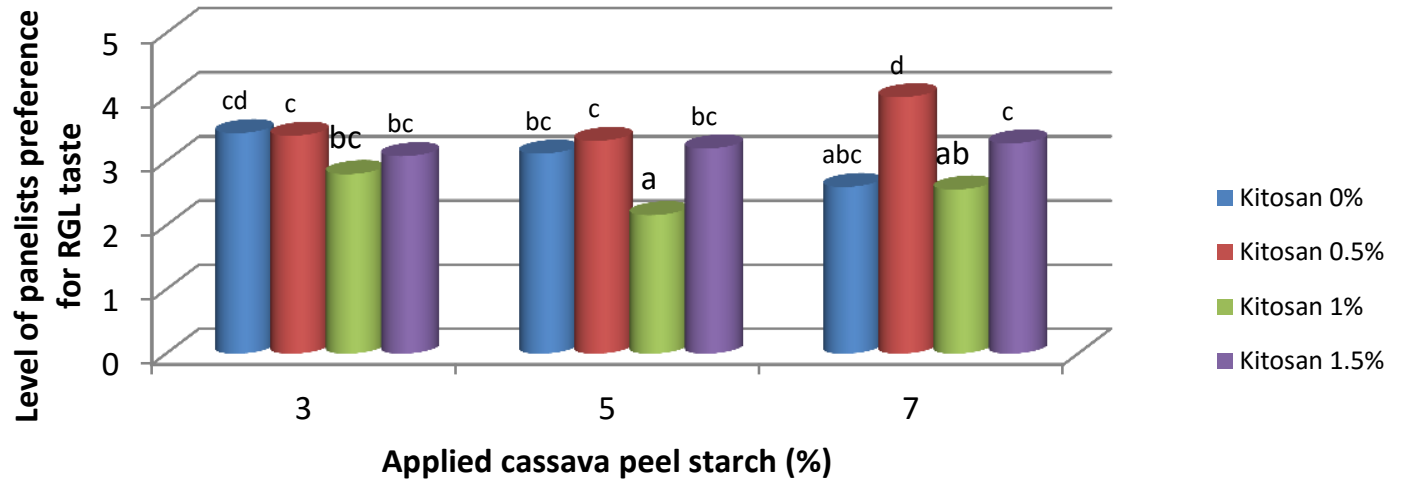

Note: the same notation above each treatment shows no significant difference at level 5\%

Figure 4. Graph of panelist preference level on taste of RGL citrus fruits coated in starch cassava peels plus chitosan and stored at room temperature for 20 days

In conclusion, assessment of organoleptic testing, panelist preference for taste of RGL orange is high, and so are for the the texture and color; but not in the flavour of RGL orange; therefore, by applying cassava peel starch and chitosan as edible coating for RGL orange could preserved the fruit up to 20 days.

\section{CONCLUSION}

1. Organoleptic quality of color, aroma, texture and taste of RGL citrus fruits coated with of starch from cassava peel plus chitosan are as follows:

a. The color of the orange that the panelists liked was absent; the highest level of panelist preference is neutral, if the starch used is 3\% with chitosan $0 \%$ (value 3.92); and if starch is $7 \%$ with chitosan $0.5 \%$ (score 3.44 ).

b. The preferred flavour of orange is absent; the panelists' liking to the highest scentis neutral, if starch is $5 \%$ with chitosan 1.5\% (score 3.12); and if if $7 \%$ starch with chitosan $0.5 \%$ (score 3.04).

c. The texture of the orange is preferred to be absent; the level of panelist preference on the highest texture is neutral, if starch is $7 \%$ with chitosan $0.5 \%$ (score 3.60); and if starch is 3\% with chitosan $0.5 \%$ (score 3.56 )

d. The taste of citrus fruits is preferred if starch is $7 \%$ with chitosan $0.5 \%$ (score $4.00)$; and if starch $3 \%$ with chitosan $0 \%$ (score 3.44 ).

2. RGL citrus fruits could be stored at room temperature for up to 20 days with (neutral characteristic - preferred), if they are given a cassava starch coating $7 \%$ and $0.5 \%$ chitosan.

\section{AKNOWLEDGEMENT}

The writer would like to thanks to the Directorate of Research and Service to 
Society, Directorate General of Research and Development, Ministry of Research, Technology and Higher Education of the Republic of Indonesia by providing grants in the Lecturer Research scheme Beginner Field for Food and Agriculture Focus in 2019 funding, Number:106 / SP2H / LT / DRPM / 2018 Date 26 March 2018, through the Beginner Lecturer Research (PDP) scheme. And also to the Research and Community Service Institute (LPPM) of Dehasen University Bengkulu for the help and cooperation so that this research can run well and smoothly.

\section{REFERENCES}

Association Of Agriculture Chemist. 1990. Official Methods of Analysis of the Association of Agriculture Chemist A.O.A.C, Washington D.C.

Akbar, F., Z. Anita, dan H. Harahap. 2013. Pengaruh Waktu Simpan Film Plastik Biodegradasi dari Pati Kulit Ubi kayu Terhadap Sifat Mekanikalnya. Jurnal Teknik Kimia USU 2(2): 11-15.14

Badan Pusat Statistik. 2017. Provinsi Bengkulu dalam Angka Tahun 2017. BPS. go.id

Budiman. 2011. Aplikasi Pati Singkong sebagai Bahan Edible Coating untuk Memperpanjang Umur Pisang Cavebdish (Musa cavendishii.). Fakultas Pertanian. Intistut Pertanian Bogor. Skripsi.

Camatari, F., L. Santana, M. Carnelossi, A. Alexander, M. Nunes, M. Goulart, N. Narain, dan M. Silva. 2017. Impact of Edible Coatings Based on Casssava Starch and Chitosan on the PostHarvest Shelf Life of Mango (Mangifera indica) "Tommy Atkins" Fruits. Food Science and Technology.

Cortez-Mazatán, G.Yakeline, L.A.ValdezAguilar, R.H. Lira-Saldivar; dan R.D.Peralta-Rodríguez. 2011. Polyvinyl Acetate As An Edible
Coating For Fruits. Effect On Selected Physiological And Quality Characteristics Of Tomato. Revista Chapingo Serie Horticultura 17(1), pages : 15-22.

Fajri, R. M., dan P. Shanti. 2018. Pengaruh Edible Coating Berbasis Pektin dan Kitosan yang Diinkorporasi dengan Nanopartikel ZnO terhadap Kesegaran Buah Mangga (Mangifera Indica L.). Technopex intitut Teknologi Indonesia. Hal : 158-166

Fitiriani, H. 2017. Pengolahan Kulit Umbi Ubi kayu (Manihot utilisima) di Kawasan Kampung Adat Cireundeu sebagai Bahan Baku Alternatif Perintang Warna Pada Ikan. eProceeding of Art and design 4(3): 1109-1119.

Hassan, H., Z.., S. Lesmayati, R. Qomariah, and A.Hasbianto. 2014. Effects of wax coating applications and storage temperatures on the quality of tangerine citrus (Citrus reticulata) var. Siam Banjar. International Food Research Journal 21(2), pages : 641-648.

Heatherbell, D.A., M.S. Reid, R.E.Wrolstad. 1982. The tamarillo : chemical composition during growth and maturation. New Zealand J.Sci. 25:239243.

Julianti, E. 2011. Pengaruh Tingkat Kematangan dan Suhu Penyimpanan terhadap Mutu Buah Terong Belanda (Cyphomandra betacea). Jurnal Hortikultur Indonesia 2(1) : 14-20.

Mahadin, M. 2015. Aplikasi Edible Coating Berbasis Pati Singkong untuk Memperpanjang Umur Simpan Buah Naga Terolah Minimal. Fakultas Teknologi Pertanian. Institut Pertanian Bogor. Skripsi

Miskiyah, widaningrum, dan C. Winarti. 2011. Aplikasi Edible Coating berbasis 
pati sagu dengan penambahan vitamin C pada Paprika: Preferensi Konsumen dan Mutu Mikrobiologi. Jurnal Hortikulturan 21(1): 68-76.

Misni, Nurlina, dan I. Syahbanu. 2017. Pengaruh Penggunaan Edible Coating Berbahan Pati Talas dan Kitosan Terhadap Kualitas Kerupuk Basah Khas Kapuas Hulu Selama Penyimpanan. JKK 7(1): 10-19.

M. Moalemiyan, H.S. Ramaswamy, N. Maftoonazad. 2012. "Pectin-based edible coating for shelf- life extension of ataulfo mango. "Journal of Food Process Engineering, 35(4), hlm. 572600, 2012.

Pantastico, E.R.B. 1989. Fisiologi Pasca Panen, Penanganan dan Pemanfaatan Buah-Buahan dan Sayur-Sayuran Tropika dan Subtropika. Gadjah Mada Univercity Pres, Yogyakarta

Pratiwi, R. 2014. Manfaat Kitin dan Kitosan Bagi Kehidupan Manusia. Jurnal Oseana 39(1): 35-43.

Rambe, S.S.M dan L.Ivanti. 2013. Pengaruh Pemupukan dan Pemangkasan terhadap Kulitas Buah Jeruk Gerga Lebong. Prosiding. http:Bengkulu.litbang.pertanian.go.id. (diakses 15 agustus 2018)

Rosalina, Y., Suprapti, W., Asima, R., Joko, P. 2015. Application of Edible Coating in Rimau Gerga Lebong Orange (RGL Orange) at Room Temperature Storage. Proceeding on International Seminar on Promoting Local Resources for Food and Health. 12-13 October 2015, Bengkulu, Indonesia. Hal. 87-93.

Santoso, B., D. Saputra, dan R. Pambuyan. 2004. Kajian Teknologi Edible Coating dari Pati dan Aplikasinya untuk Pengemas Primer Lempok Durian. Jurnal Teknologi dan Industri Pangan 15(3): 239-252.
Sarwono, R. 2010. Pemanfaatan Kitn/Kitosan sebagai Bahan Anti Mikroba. JKTI 12(1):32-38.

Sunarmani, D.A., W.Broto, dan S. Sentausa. 1996. Pengaruh Komposisi O2 dan CO2 dalam Wadah Tertutup terhadap Mutu dan Daya Simpan Nanas. Jurnal Hortikultura 5 (5): 80-93.

Surahman, D., E.K. Apriliyadi, H. Astro, T. Rahman. 2016. Potensi Pemanfaatan Jeruk Gerga Sebagai Upaya Diversifikasi Pangan di Kabupaten Rejang Lebong Melalui Pemanfaatn Teknologi Tepat Guna.Prosiding Konferensi san seminar Nasional Teknologi Tepat Guna:280-288.

Widianingrum, Miskiyah, dan C. Winarti. Edible Coating Berabsis Pati Sagu dengan Penambahn Minyak Sereh Pada Paprika: Preferensi Konsumen dan Mutu Vitamin C. Jurnal Agritech 35(1): 53-59.

Winarti, C., Miskiyah, dan Widaningrum. 2012. Teknologi Produksi dan Aplikasi Pengemas Edible Antimikroba Berbasis Pati. Jurnal Litbang Pertanian 31(3):8593.

Wilda, M., L. Ivanti, T. Hidayat, Zainani, D. A. Juniansyah. 2015. Pengkajian Peningkatan Nilai Tambah Buah Jeruk Spesifik Bengkulu. Balai Pengkajian Teknologi Pertanian Bengkulu.

Wills, R.H., T.H. Lee, D. Graham, Mc. 2000. Gkasson, W.B. Hall, 1981. Postharvest, An Introduction to The Physiology and Handling of Fruits and Vegetables. New South Wales University Press, Kensington, Australia.

Y. Jiang, D.C. Joyce, A.J. Macnish. 2000. "Effect of abscisic acid on banana fruit in relation to role of ethylene." Journal Plant Growth Regulation, 19(1): 106111 